\title{
Bioaccumulation of Heavy Metals in the Mussel Mytilus galloprovincialis in the Changseon area, Korea, and Assessment of Potential Risk to Human Health
}

\author{
Jong Soo Mok ${ }^{1}$, Hyun Duk Yoo ${ }^{1}$, Poong Ho Kim ${ }^{1}$, Ho Dong Yoon ${ }^{1}$, Young Cheol Park ${ }^{1}$, Ji Hoe Kim², \\ Ji Young Kwon ${ }^{2}$, Kwang Tae Son ${ }^{2}$, Hee Jung Lee ${ }^{2}$, Kwang Soo $\mathrm{Ha}^{2}$, Kil Bo Shim ${ }^{2}$, Mi Ra Jo ${ }^{2}$ and Tae Seek Lee \\ ${ }^{1}$ Southeast Sea Fisheries Research Institute, National Fisheries Research and Development Institute, Tongyoung 650-943, Korea \\ ${ }^{2}$ Food Safety Research Division, National Fisheries Research and Development Institute, Busan 619-705, Korea
}

\begin{abstract}
From 2008 to 2013, the mussel Mytilus galloprovincialis were collected from a major area of mussel production (Changseon area), which is a designated shellfish-cultivating area for export, located on the southern coast of Korea. The samples were analyzed for mercury $(\mathrm{Hg})$ using a direct $\mathrm{Hg}$ analyzer and for other metals, such as cadmium $(\mathrm{Cd})$, lead $(\mathrm{Pb})$, arsenic $(\mathrm{As})$, chromium, copper, nickel, and zinc, using inductively coupled plasma mass spectrometry. The concentrations and bioaccumulation of the heavy metals were determined, and a potential risk assessment was conducted to evaluate their hazards towards human consumption. The concentration and bioaccumulation ratio of $\mathrm{Cd}$ were the highest of the three hazardous metals $(\mathrm{Cd}, \mathrm{Pb}$, and $\mathrm{Hg})$. The concentrations of hazardous metals in all samples were within the limits set by Korea and other countries. The estimated dietary intake (EDI) was compared to the provisional tolerable daily intake (PTDI) adopted by the Joint FAO/WHO Expert Committee on Food Additives and the U.S. Environmental Protection Agency. The EDIs of all heavy metals tested for mussel samples ranged from 0.01 to $4.99 \%$ of the PTDI; the highest value was measured for As. The hazard index (HI) can be used to assess the risk of heavy metal consumption associated with contaminated food. The HI for all samples was far less than 1.0, which indicates that the mussels produced in the Changseon area do not represent an appreciable hazard to humans and are fit for consumption.
\end{abstract}

Key words: Mytilus galloprovincialis, Heavy metal, Bioaccumulation, Mussel, Korea

\section{Introduction}

Fishery products are an important global food resource. According to the Food and Agriculture Organization of the United Nations (FAO, 2009), Korea was the world's seventh greatest consumer of fishery products in 2009 , accounting for $56.1 \mathrm{~kg} /$ person/year, which is three-fold higher than the global average consumption. FAO (2012) also reported that Korea produced 737,855 tons of molluscan shellfish in 2011, which ranked fourth in the world, accounting for almost $3.5 \%$ of global production. According to Statistics Korea (2013), the country produced 61,310 tons of mussels in 2012 , the second largest amount of shellfish produced in Korea. Gyeongnam province produced the largest amount of mussel in Korea, accounting for about $85 \%$ of the mussel products in Korea. The Korean government has established a memorandum of understanding with the European Union (EU), and there are designated shellfish-cultivation areas for export along the southern coast of Korea that meet the standards set by the EU (Lee et al., 2011). The Changseon area, located in Gyeongnam prov-
(C) 2014 The Korean Society of Fisheries and Aquatic Science This is an Open Access article distributed under the terms of the Creative Commons Attribution Non-Commercial Licens (http://creativecommons. org/licenses/by-nc/3.0/) which permits unrestricted non-commercial use, distribution, and reproduction in any medium, provided the original work is properly cited.
Received 10 July 2014; Revised 24 July 2014

Accepted 25 July 2014

*Corresponding Author

E-mail: tslee2855@korea.kr 
ince, has been the designated shellfish-cultivation area for export since 2009 because it is an important mussel-cultivation area in Korea (Ha et al., 2013). The products are consumed domestically or exported mainly to the EU (Mok et al., 2013). Therefore, the safety of Korean seafood is very important to Korea and importing countries, including the EU.

Heavy metals found naturally in the environment vary widely. Heavy metals such as arsenic (As), cadmium (Cd), chromium $(\mathrm{Cr})$, copper $(\mathrm{Cu})$, lead $(\mathrm{Pb})$, mercury $(\mathrm{Hg})$, nickel $(\mathrm{Ni})$, and zinc $(\mathrm{Zn})$ accumulate generally in marine organisms from the aquatic environment, especially in various species of molluscan shellfish (Kobal et al., 2004; Mora et al., 2004; Borak and Hosgood, 2007; Mok et al., 2010). Some hazardous metals (As, $\mathrm{Cd}, \mathrm{Cr}, \mathrm{Hg}$, and $\mathrm{Pb}$ ) that accumulate in molluscan shellfish pose a health risk to humans, even in trace amounts (EOS Ecology, 2012; Mok et al., 2014). To protect public health, Korean authorities have established regulatory limits and monitoring programs for three hazardous metals, namely, $\mathrm{Cd}, \mathrm{Pb}$, and $\mathrm{Hg}$, to determine whether shellfish are safe to consume (KMFDS, 2014). Heavy metal contamination can be hazardous to humans; therefore, the concentrations of heavy metals in shellfish from the aquatic environment must be monitored regularly to provide information on the hazard levels for the consumer. The accumulation of heavy metals in marine organisms depends on both their uptake and elimination rates. Heavy metals are taken up through various organs and concentrated at different levels (Guven et al., 1999).

In the present study, we determined the concentration and bioaccumulation of heavy metals in the mussel Mytilus galloprovincialis collected from the Changseon area on the southern coast of Korea. Dietary intake of heavy metals via consumption of mussels depends on both the metal concentration in the animal and the amount of this animal consumed. The estimated dietary intake (EDI) of heavy metals via mussel consumption was compared to the provisional tolerable daily intake (PTDI) established by the Joint FAO/WHO Expert Committee on Food Additives (JECFA, 1999; 2010a, b) and the U.S. Environmental Protection Agency (EPA, 2013). In addition, an assessment of the potential risk of heavy metals in mussels was performed using the target hazard quotient (THQ) and hazard index (HI).

\section{Materials and Methods}

\section{Reagents and standard solutions}

Supra-pure grade nitric acid (Merck, Darmstadt, Germany) was used for sample preparation. Deionized water (DIW) was passed through a Milli-Q water purification system (Millipore, Billerica, MA, USA). Working standard solutions of $\mathrm{Cd}, \mathrm{Pb}$, $\mathrm{As}, \mathrm{Cr}, \mathrm{Cu}, \mathrm{Ni}$, and $\mathrm{Zn}$ were prepared by diluting $1,000 \mathrm{mg} / \mathrm{L}$ standard solutions (Merck, Darmstadt, Germany) in DIW for the calibration. MESS-3, a marine sediment certified reference

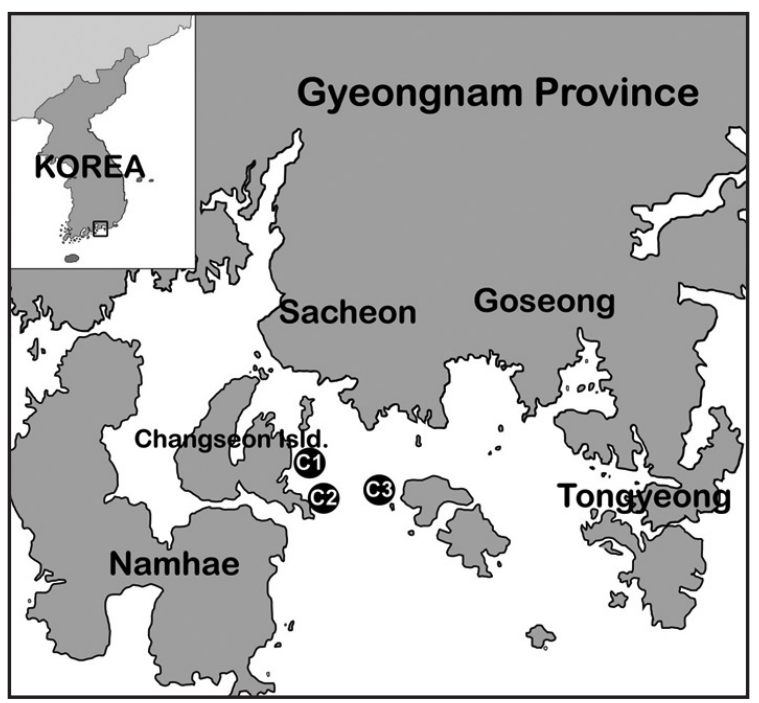

Fig. 1. Sampling locations in Changseon area on the south coast in Korea.

material (CRM), was purchased from the National Research Council of Canada (NRCC, Ottawa, ON, Canada) and used as a calibration standard for $\mathrm{Hg}$.

\section{Field sampling}

Samples were collected twice a year from 2008 through 2013 at fixed monitoring stations in the Changseon area, which is the designated shellfish-cultivation area for export, located on the southern coast of Korea (Fig. 1). In the Changseon area, 28 mussel samples $M$. galloprovincialis were collected at 2-3 $\mathrm{m}$ depths from a hanging rope culture. The sample of surface seawater was collected only from station 3 in February 2012. The samples were received in a condition suitable for analysis, preferably chilled in coolers, and transported to the laboratory. To minimize variation among individual mussels, one sample unit was composed of more than 12 animals collected at the same station. The mean value \pm standard deviation (SD) of the total width and length of samples was $3.5 \pm 0.3$ and $6.5 \pm 0.4$ $\mathrm{cm}$, respectively.

\section{Sample preparation}

The mussel samples were immediately washed with tap water and DIW upon reception and the shells of the mussels were shucked. The tissue samples were cleaned with DIW, homogenized, and weighed. The homogenized tissues were freezedried with a vacuum freeze dryer (FDU-2100, EYELA, Tokyo, Japan) and then ground into powder for analysis. About $1.0 \mathrm{~g}$ powdered sample was placed in a $60 \mathrm{~mL}$ digestion vessel (Savillex, Eden Prairie, MN, USA), after which $20 \mathrm{~mL}$ nitric acid was added. The vessel was covered and left overnight at 
room temperature. The samples were digested with a heating digester (DigiPREP HP, SCP Science, Champlain, NY, USA), and more nitric acid was added to samples that were not completely digested. The completely digested samples were allowed to cool to room temperature, dissolved in $2 \%$ nitric acid, filtered (glass wool), and their volumes were increased to $100 \mathrm{~mL} \mathrm{2 \%} \mathrm{nitric} \mathrm{acid} \mathrm{to} \mathrm{analyze} \mathrm{all} \mathrm{heavy} \mathrm{metals,} \mathrm{excluding}$ $\mathrm{Hg}$. Approximately $0.1 \mathrm{~g}$ homogenized sample was used for the $\mathrm{Hg}$ analysis.

\section{Heavy metal analysis}

All digested samples were analyzed in triplicate for $\mathrm{Cd}$, $\mathrm{Pb}, \mathrm{As}, \mathrm{Cr}, \mathrm{Cu}, \mathrm{Ni}$, and $\mathrm{Zn}$ using inductively coupled plasma mass spectrometry (ICP-MS; ELAN DRC II, PerkinElmer, Waltham, MA, USA). Total $\mathrm{Hg}$ concentration in homogenized samples was measured directly in triplicate with a combustion gold amalgamation method using a direct mercury analyzer (DMA-80, Milestone, Milano, Italy). The blanks, calibration standards, and CRMs were analyzed using the same methods. The concentrations of heavy metals were expressed in micrograms per gram of wet weight sample.

The accuracy of the heavy metal analysis method was assessed using the SRM-1566b (oyster tissue) CRM provided by the National Institute of Standards and Technology (NIST, Gaithersburg, MD). The quantitative recoveries of heavy metals in the oyster tissue CRM $(n=5)$ ranged from $91.1 \%$ to $107.7 \%$, which were within the acceptable values recommended by AOAC International (2002).

\section{Statistical analysis}

Statistical evaluation was conducted using analysis of variance (ANOVA) with the general linear model (GLM) procedure (version 9.2, SAS Institute, Cary, NC, USA). Duncan's multiple-range test was applied to determine the significance of differences between the mean concentrations of heavy metals in the mussel samples.

\section{Results and Discussion}

\section{Concentration and bioaccumulation of heavy metals in mussel}

The mean, standard deviation, and range of concentrations of the heavy metals analyzed in the mussels collected from three fixed stations in the Changseon area are shown in Table 1. The selected metals have been monitored regularly in the designated shellfish-cultivation areas in the EU and Korea. The mean concentrations in mussel samples decreased significantly $(P<0.05)$ in the order $\mathrm{Zn}(15.91 \mu \mathrm{g} / \mathrm{g})>\mathrm{As}(2.255$ $\mu \mathrm{g} / \mathrm{g})>\mathrm{Cu}(1.501 \mu \mathrm{g} / \mathrm{g})>\mathrm{Ni}(0.358 \mu \mathrm{g} / \mathrm{g})>\mathrm{Cr}(0.234 \mu \mathrm{g} / \mathrm{g})$ $>\mathrm{Cd}(0.197 \mu \mathrm{g} / \mathrm{g})>\mathrm{Pb}(0.159 \mu \mathrm{g} / \mathrm{g})>\mathrm{Hg}(0.007 \mu \mathrm{g} / \mathrm{g})$. However, the differences among mussels among stations were not significant. The mean concentrations of heavy metals in mussels were similar to that collected from fish markets in Korea (Mok et al., 2014).

Some heavy metals such as $\mathrm{Cd}, \mathrm{Hg}, \mathrm{Pb}, \mathrm{As}$, and $\mathrm{Cr}$ can harm humans, even in trace amounts. The mean concentrations of As at each mussel station, which were the highest of the hazardous metals, ranged from 2.003 to $2.631 \mu \mathrm{g} / \mathrm{g}$, with the highest found at station $\mathrm{C} 2$. The mean $\mathrm{Cd}$ concentrations in mussel samples at each station, which were the highest of the three hazardous metals $(\mathrm{Cd}, \mathrm{Pb}$, and $\mathrm{Hg})$ within the regulatory limits established by Korea (KMFDS, 2014), ranged from 0.167 to $0.234 \mu \mathrm{g} / \mathrm{g}$. The mean Cd concentration in all mussels from throughout the Changseon area was $0.197 \mu \mathrm{g} / \mathrm{g}$, less than the 0.510 and $0.288 \mu \mathrm{g} / \mathrm{g}$ for shellfish reported by Sho et al. (2000) and Ham (2002), respectively, in Korea. Our result is slightly lower than the average levels of 0.22 and 0.224 $\mu \mathrm{g} / \mathrm{g}$ for shellfish in India (Sivaperumal et al., 2007) and China

Table 1. Heavy metal concentrations in the mussel Mytilus galloprovincialis and seawater collected from the Changseon area on the south coast in Korea

\begin{tabular}{lcccccccc}
\hline $\begin{array}{c}\text { Stations } \\
\text { (number of } \\
\text { samples) }\end{array}$ & $\mathbf{C d}$ & $\mathbf{H g}$ & $\mathbf{P b}$ & $\mathbf{A s}$ & $\mathbf{C r}$ & $\mathbf{C u}$ & $\mathbf{N i}$ & $\mathbf{Z n}$ \\
\cline { 2 - 10 } & & & & & & & & \\
Mussel & & & & & & & \\
C 1 (12) & $0.185 \pm 0.083$ & $0.008 \pm 0.004$ & $0.160 \pm 0.105$ & $2.276 \pm 1.054$ & $0.250 \pm 0.129$ & $1.524 \pm 0.656$ & $0.363 \pm 0.219$ & $15.67 \pm 5.41$ \\
& $(0.120-0.434)$ & $(0.003-0.015)$ & $(0.066-0.426)$ & $(1.020-4.370)$ & $(0.089-0.521)$ & $(0.732-2.448)$ & $(0.162-0.820)$ & $(10.62-28.15)$ \\
C 2 (8) & $0.167 \pm 0.067$ & $0.006 \pm 0.002$ & $0.162 \pm 0.041$ & $2.631 \pm 0.960$ & $0.190 \pm 0.160$ & $2.005 \pm 1.159$ & $0.507 \pm 0.159$ & $19.00 \pm 6.00$ \\
& $(0.103-0.234)$ & $(0.004-0.008)$ & $(0.130-0.221)$ & $(1.846-4.030)$ & $(0.094-0.430)$ & $(1.061-3.679)$ & $(0.349-0.649)$ & $(12.32-24.36)$ \\
C 3 (8) & $0.234 \pm 0.032$ & $0.006 \pm 0.003$ & $0.155 \pm 0.184$ & $2.003 \pm 0.566$ & $0.233 \pm 0.085$ & $1.172 \pm 0.394$ & $0.263 \pm 0.149$ & $14.54 \pm 2.27$ \\
& $(0.170-0.269)$ & $(0.003-0.010)$ & $(0.020-0.553)$ & $(1.560-3.128)$ & $(0.140-0.342)$ & $(0.814-1.948)$ & $(0.134-0.550)$ & $(11.47-16.97)$ \\
Total & $0.197 \pm 0.071$ & $0.007 \pm 0.003$ & $0.159 \pm 0.122$ & $2.255 \pm 0.902$ & $0.234 \pm 0.120$ & $1.501 \pm 0.722$ & $0.358 \pm 0.201$ & $15.91 \pm 4.83$ \\
& $(0.103-0.434)$ & $(0.003-0.015)$ & $(0.020-0.553)$ & $(1.020-4.370)$ & $(0.089-0.521)$ & $(0.732-3.679)$ & $(0.134-0.820)$ & $(10.62-28.15)$ \\
Seawater & $2.6 \times 10^{-6}$ & $2.3 \times 10^{-7}$ & $8.4 \times 10^{-6}$ & $4.8 \times 10^{-5}$ & $5.5 \times 10^{-4}$ & $3.1 \times 10^{-3}$ & - & $1.0 \times 10^{-3}$ \\
\hline
\end{tabular}


(Li et al., 2013), respectively. All samples had Cd concentrations within the regulatory limits $(1.0$ to $2.0 \mu \mathrm{g} / \mathrm{g})$ set by the Codex Alimentarius Commission $(2.0 \mu \mathrm{g} / \mathrm{g})(2006)$ and other countries such as Korea $(2.0 \mu \mathrm{g} / \mathrm{g})$ (KMFDS, 2014), Australia, New Zealand (both $2.0 \mu \mathrm{g} / \mathrm{g}$ ) (FSANZ, 2008), and the EU $(1.0 \mu \mathrm{g} / \mathrm{g})(\mathrm{EC}, 2001)$. The mean $\mathrm{Hg}$ concentrations of the samples at each station ranged from 0.006 to $0.008 \mu \mathrm{g} / \mathrm{g}$, far lower than the limit $(0.5 \mu \mathrm{g} / \mathrm{g})$ in Korea (KMFDS, 2014) and the EU (EC, 2005). The mean level $(0.007 \mu \mathrm{g} / \mathrm{g})$ of $\mathrm{Hg}$ in all mussel samples was three- to four-fold lower than the levels for shellfish reported in other Korean studies (Ham, 2002; Sho et al., 2000). The mean $\mathrm{Hg}$ level was similar to the $0.008 \mu \mathrm{g} / \mathrm{g}$ reported for Chinese shellfish (Li et al., 2013).

The highest $\mathrm{Pb}$ concentration $(0.553 \mu \mathrm{g} / \mathrm{g})$ was about twoto four-fold lower than the regulatory limits (1.0 to $2.0 \mu \mathrm{g} / \mathrm{g}$ ) set by various countries, e.g., $2.0 \mu \mathrm{g} / \mathrm{g}$ in Korea (KMFDS, 2014), Australia, and New Zealand (FSANZ, 2008) and 1.0 $\mu \mathrm{g} / \mathrm{g}$ in the EU (EC, 2001). The Korean authority has established a memorandum of understanding with the EU; thus, the shellfish products harvested from the designated shellfish-cultivation areas (Changseon area, etc.) can only be exported to the EU (Lee et al., 2011). Therefore, because the heavy metals of mussels produced in the Changseon area meet the standards established by the EU, it is possible to export mussels to the EU.

The mean bioaccumulation ratios in all mussels from surrounding seawater ranged from 429- to 74,794-fold; the highest ratio was found for $\mathrm{Cd}$ (Fig. 2A). The metals in mussels accumulated in the order $\mathrm{Cd}>\mathrm{As}>\mathrm{Hg}>\mathrm{Pb}>\mathrm{Zn}>\mathrm{Cu}>$ $\mathrm{Cr}$; however, the differences between $\mathrm{Pb}$ and $\mathrm{Zn}$ and between $\mathrm{Cr}$ and $\mathrm{Cu}$ were not significant. The metal bioaccumulation ratio in mussels was relatively high for $\mathrm{Cd}, \mathrm{Hg}, \mathrm{Pb}, \mathrm{As}$, and $\mathrm{Zn}$ but low for $\mathrm{Cr}$ and $\mathrm{Cu}$. The accumulation of contaminants in aquatic organisms depends on both their uptake and elimination rates (Guven et al., 1999). Heavy metals are taken up through various organs and concentrated at different levels in each organ (Bustamante et al., 2000; Sivaperumal et al., 2007; Abdallah, 2013).

Even trace concentrations of some heavy metals such as $\mathrm{Cd}, \mathrm{Hg}$, and $\mathrm{Pb}$ can harm humans. Korea has established regulatory limits and has monitoring programs for these three hazardous metals to protect the public that consumes fishery products (Mok et al., 2014). The concentration and bioaccumulation ratio of $\mathrm{Cd}$ were the highest of the three hazardous metals. The concentrations of these harmful metals in all samples were below the regulatory limits established by Korea, the EU, Australia, and New Zealand.

\section{Dietary intake estimation and risk assessment of heavy metals via consumption of mussel}

The EDIs of heavy metals represent the daily intake of heavy metals through the consumption of mussels for an adult. The EDI was compared to the PTDI proposed by the JECFA
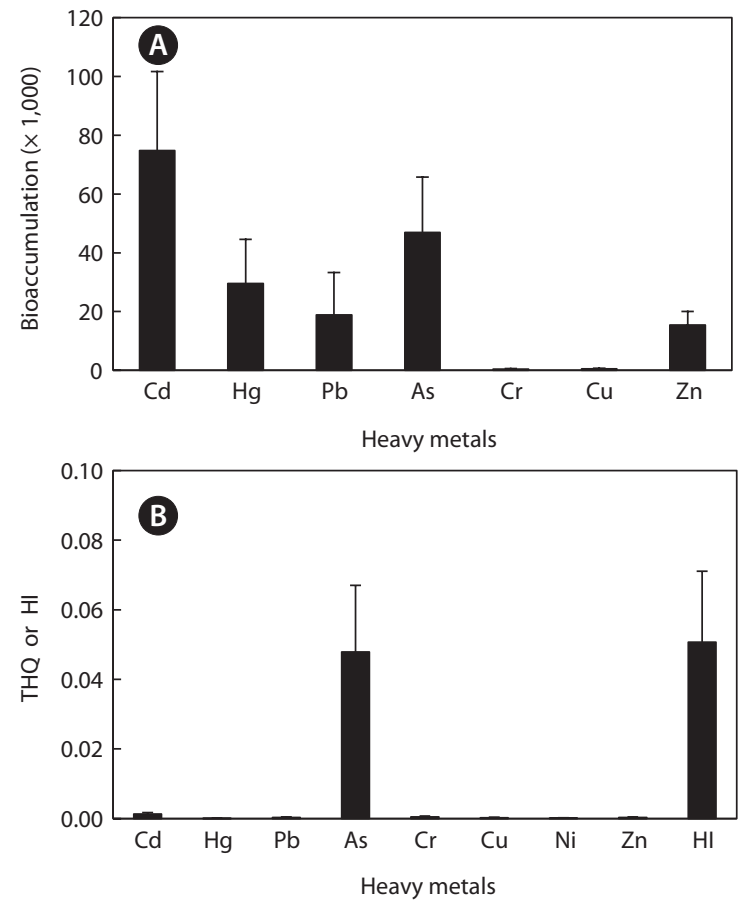

Fig. 2. Bioaccumulation ratio (A) of heavy metals in mussel Mytilus galloprovincialis, and target hazard quotients (THQs) and hazard index (HI) (B) for heavy metals via consumption of mussel in Korea. Scale bars represent one standard deviation.

The bioaccumulation ratio was calculated as the mean metal concentration in a gram of mussel divided by that in a milliliter of seawater shown in Table 1.THQs were represented according to the U. S. Environmental Protection Agency (EPA) Human Health Risk Assessment approach (US $E P A, 2013)$. The THQ was calculated using the equation $T H Q=(E F \times E D \times$ $\mathrm{DI} \times \mathrm{HC}$ ) / ( $\mathrm{RFD} \times \mathrm{BW} \times \mathrm{ET})$, where $\mathrm{EF}$ is the exposure frequency (350 days/ year); $E D$ is the exposure duration (81 years), equivalent to the average lifetime in Korea (Statistics Korea, 2013); DI is the average daily intake $(0.0066 \mu \mathrm{g} / \mathrm{kg} /$ day $)$ of mussel based on Korean health statistics 2010 (KCDC, 2011); HC is the heavy-metal content in each tissue of mussel ( $\mu \mathrm{g} /$ g) shown in Table 1; RfD is the oral reference dose $(\mu \mathrm{g} / \mathrm{kg} /$ day); BW is the average body weight $(62.8 \mathrm{~kg})$ of an adult based on 2010 Korean health statistics (KCDC, 2011); and ET is the average exposure time for noncarcinogens (ED $\times 365$ days/year). The $\mathrm{RfD}$ values of $\mathrm{Hg}, \mathrm{Pb}, \mathrm{As}, \mathrm{Cr}, \mathrm{Cu}, \mathrm{Ni}$, and $\mathrm{Zn}$ are used as the provisional tolerable daily intake shown in Table 2. RfD value of $C d$ were set at 1.0 established by the EPA (2013). HI was calculated by summing the target hazard quotients of individual heavy metals.

(1999; 2010a; 2010b) and the EPA (2013). The provisional tolerable weekly intake (PTWI) for $\mathrm{Hg}$ and $\mathrm{Pb}$ (JECFA, 1999; 2010a) and the provisional tolerable monthly intake (PTMI) for Cd (JECFA, 2010b) were established by the JECFA because of the risks of even trace concentrations of these metals to human health.

As shown in Table 2, the EDI values of the hazardous heavy metals $(\mathrm{Cd}, \mathrm{Hg}$, and $\mathrm{Pb})$ for mussel samples were $1.3 \times 10^{-3}$, $4.5 \times 10^{-5}$, and $1.1 \times 10^{-3} \mu \mathrm{g} / \mathrm{kg} /$ day, respectively, which account for only 0.01 to $0.16 \%$ of the PTDI. The EDIs of other metals (As, $\mathrm{Cr}, \mathrm{Cu}, \mathrm{Ni}$, and $\mathrm{Zn}$ ) were compared to the PTDI values based on the reference doses established by the EPA (2013). 
Table 2. Estimated dietary intakes (EDIs) of heavy metals via consumption of the mussel Mytilus galloprovincialis collected from Changseon area on the south coast in Korea

\begin{tabular}{lccccccccc}
\hline & \multicolumn{9}{c}{ Heavy metals } \\
\cline { 2 - 8 } & $\mathbf{C d}$ & $\mathbf{H g}$ & $\mathbf{P b}$ & $\mathbf{A s}$ & $\mathbf{C r}$ & $\mathbf{C u}$ & $\mathbf{N i}$ & $\mathbf{Z n}$ \\
\hline EDIs $(\mu \mathrm{g} / \mathrm{kg} / \mathrm{day})^{1}$ & $1.3 \times 10^{-3}$ & $4.5 \times 10^{-5}$ & $1.1 \times 10^{-3}$ & $1.5 \times 10^{-2}$ & $1.6 \times 10^{-3}$ & $1.0 \times 10^{-2}$ & $2.4 \times 10^{-3}$ & $1.1 \times 10^{-1}$ \\
PTDI values $(\mu \mathrm{g} / \mathrm{kg} / \text { day })^{2}$ & 0.83 & 0.57 & 3.57 & 0.3 & 3.0 & 40 & 20 & 300 \\
\hline
\end{tabular}

${ }^{1}$ The EDI value for an adult was calculated according to the equation EDI (in $\left.\mu \mathrm{g} / \mathrm{kg} / \mathrm{day}\right)=(\mathrm{HC} \times \mathrm{DI}) / \mathrm{BW}$, where $\mathrm{HC}$ is the mean heavy - metal concentration in the mussel shown in Table 1, DI and BW are the average daily intake $(0.0066 \mu \mathrm{g} / \mathrm{kg} / \mathrm{day})$ of mussel and the average body weight (62.8 $\mathrm{kg})$ of an adult based on Korean health statistics 2010 (KCDC, 2011).

${ }^{2}$ The provisional tolerable daily intake (PTDI) values of $\mathrm{Hg}, \mathrm{Pb}$, and $\mathrm{Cd}$ were based on the provisional tolerable weekly intake (PTWI) data ( $\mathrm{Hg}$, $\mathrm{Pb}$ ) and provisional tolerable monthly intake data (Cd) of the Joint FAO/WHO Expert Committee on Food Additives (JECFA, 1999; 2010a, 2010b), in which the PTWI value of inorganic $\mathrm{Hg}$ was adopted as that for total $\mathrm{Hg}$. The PTDI values of other metals, such as As (assuming that total As is inorganic As), $\mathrm{Cr}$ (assuming that total $\mathrm{Cr}$ is $\mathrm{Cr} \mathrm{VI}), \mathrm{Cu}, \mathrm{Ni}$ (assuming that all $\mathrm{Ni}$ is Ni soluble salts), and $\mathrm{Zn}$ (assuming that all $\mathrm{Zn}$ is $\mathrm{Zn}$ and compounds), were based on the oral reference doses established by the U. S. Environmental Protection Agency (EPA, 2013).

In these mussels, the EDI values of $\mathrm{As}, \mathrm{Cr}, \mathrm{Cu}, \mathrm{Ni}$, and $\mathrm{Zn}$ accounted for $4.99 \%, 0.05 \%, 0.02 \%, 0.01 \%$, and $0.04 \%$ of the PTDI, respectively. The EDI value for As was the highest of all tested metals, which is due to the relatively high As concentration (Table 1) and using the PTDI value of inorganic As for total As.

The THQ and HI were used to assess the potential risk to an adult of consuming heavy metals via mussels. The THQ was estimated by comparing the ingested amount of a heavy metal with a standard reference dose; the HI was the sum of the various THQs. The THQ and HI values proposed by the EPA are integrated risk indexes, and have been used widely for risk assessment of various contaminants in foods (Storelli, 2008; Mok et al., 2014). Both THQ and HI are useful parameters for evaluating the risk of heavy metal ingestion associated with the consumption of contaminated foods (Abdallah, 2013; Mok et al., 2014).

As shown in Fig. 2B, the mean THQ of the metals was low in mussel species, ranging from 0.0001 to 0.0479 ; the highest THQ was for As. The maximum THQ of each metal in all species ranged from 0.0001 to 0.0670 , and all of the values were well below 0.1 . The THQ was relatively high for As in all samples analyzed, but low for other metals. An HI exceeding 1.0 indicates that the contaminant is toxic and represents a hazard to human health (Abdallah, 2013; Li, et al., 2013). The mean and highest HI values were 0.0507 and 0.0711 , respectively, significantly below 1.0 .

In conclusion, the concentration and bioaccumulation ratio of $\mathrm{Cd}$ in mussels were the highest of the three hazardous metals $(\mathrm{Cd}, \mathrm{Pb}$, and $\mathrm{Hg})$. The concentrations of hazardous metals in all samples were lower than the standards set by various governments. The EDIs of all heavy metals analyzed for mussels ranged from only 0.01 to $4.99 \%$ of the PTDI values suggested by the JECFA and the EPA; the highest value was for As. The HI for all mussels was far less than 1.0, which indicates that the intake of heavy metals via consumption of this animal does not pose an appreciable hazard to humans.

\section{Acknowledgments}

This work was supported by a grant from the National Fisheries Research and Development Institute of Korea (RP-2014FS-011).

\section{References}

Abdallah MAM. 2013. Bioaccumulation of heavy metals in mollusca species and assessment of potential risks to human health. Bull Environ Contam Toxicol 90, 552-557.

AOAC International. 2002. AOAC guidelines for single laboratory validation of chemical methods for dietary supplements and botanicals. Gaithersburg, MD, USA.

Borak J and Hosgood HD. 2007. Seafood arsenic: Implications for human risk assessment. Regul Toxicol Pharm 47, 204-212.

Bustamante P, Grigrioni S, Boucher-Rodoni R, Caurant F and Miramand P. 2000. Bioaccumulation of 12 trace elements in the tissues of the nautilus Natilus macromphalus from New Caledonia. Mar Pollut Bull 40, 688-696.

Codex Alimentarius Commission. 2006. Report of the 29th Session of Codex Alimentarius Commission. ALINORM 06/29/41, Geneva, Switzerland.

EOS Ecology. 2012. Heavy metals in fish and shellfish, EOS Ecology, Christchurch, New Zealand.

European Commission (EC). 2001. Commission Regulation (EC) No $466 / 2001$ of 8 March 2001 setting maximum levels for certain contaminants in foodstuffs. Accessed 26 August 2013, http://eur-lex. europa.eu/LexUriServ/LexUriServ.do?uri=OJ:L:2001:077:0001:0 013:EN:PDF.

European Commission (EC). 2005. Commission Regulation (EC) No 78/2005 of 19 January 2005 amending Regulation (EC) No 466/2001 as regards heavy metals. Accessed 26 August 2013, http://eur-lex.europa.eu/LexUriServ/LexUriServ.do?uri=OJ:L:200 5:016:0043:0045:EN:PDF.

Food and Agriculture Organization of the United Nations (FAO). 2009. Fishery and aquaculture statistics. Accessed 2 May 2014, http:// 
www.fao.org/fishery/statistics/en.

Food and Agriculture Organization of the United Nations (FAO). 2012. Fishery and aquaculture statistics. Accessed 2 May 2014, http:// www.fao.org/fishery/statistics/en.

Food Standards Australia New Zealand (FSANZ). 2008. Australia New Zealand food standards code (Incorporating amendments up to and including amendment 97). Anstat Pty Ltd., Melbourne, Australia.

Guven K, Ozbay C, Unlu E and Satar A. 1999. Acute lethal toxicity and accumulation of copper in Gammarus pulea (L) (Amphipoda). Turk J Biol 23, 513-521.

Ha KS, Yoo HD, Shim KB, Kim JH, Lee TS, Kim PH, Lee HJ and Yu HS. 2013. The effects of inland pollution sources around the port of Jeokyang and Jangpo after rainfall events on bacteriological water quality in the Changseon area, Korea. Kor J Fish Aquat Sci 46, 160-167.

Ham HJ. 2002. Distribution of hazardous heavy metals ( $\mathrm{Hg}, \mathrm{Cd}$ and $\mathrm{Pb})$ in fishery products, sold at Garak wholesale markets in Seoul. J Food Hyg Safety 17, 146-151.

Joint FAO/WHO Expert Committee on Food Additives (JECFA). 1999. Summary and conclusions of the 53rd meeting of the Joint FAO/ WHO Expert Committee on Food Additives (JECFA). JECFA/53/ SC. Rome, Italy.

Joint FAO/WHO Expert Committee on Food Additives (JECFA). 2010a. Summary and conclusions of the 72nd meeting of the Joint FAO/ WHO Expert Committee on Food Additives (JECFA). JECFA/72/ SC. Rome, Italy.

Joint FAO/WHO Expert Committee on Food Additives (JECFA). 2010b. Summary and conclusions of the 73nd meeting of the Joint FAO/WHO Expert Committee on Food Additives (JECFA). JECFA/73/SC. Geneva, Switzerland.

Kobal AB, Horvat M, Prezelj M, Briški AS, Krsnik M, Dizdarevič T, Mazej D, Falnoga I, Stibilj V, Arnerič N, Kobal D and Osredkar J. 2004. The impact of long-term past exposure to elemental mercury on antioxidative capacity and lipid peroxidation in mercury miners. J Trace Elem Med Biol 17, 261-274.

Korea Centers for Disease Control and Prevention (KCDC). 2011. Korea health statistics 2010: The fifth Korea national health and nutrition examination survey. Cheongju, Korea.

Korea Ministry of Food and Drug Safety (KMFDS). 2014. Korea food code. Accessed 21 June 2014, http://fse.foodnara.go.kr/residue/ RS/jsp/menu_02_01_01.jsp.

Lee KJ, Mok JS, Song KC, Yu HS, Jung JH and Kim JH. 2011. Geographical and annual variation in lipophilic shellfish toxins from oysters and mussels along the south coast of Korea. J Food Prot 74, 2127-2133.

Li J, Huang ZY, Hu Y and Yang H. 2013. Potential risk assessment of heavy metals by consuming shellfish collected from Xiamen, China. Environ Sci Pollut Res 20, 2937-2947.

Mok JS, Kwon JY, Son KT, Choi WS, Kang SR, Ha NY, Jo MR and Kim JH. 2014. Contents and risk assessment of heavy metals in marine invertebrates from Korean coastal fish markets. J Food Prot 77, 1022-1030.

Mok JS, Lee KJ, Shim KB, Lee TS, Song KC and Kim JH. 2010. Contents of heavy metal in marine invertebrates from the Korean coast. J Korean Soc Food Sci Nutr 39, 894-901.

Mok JS, Song KC, Lee KJ and Kim JH. 2013. Variation and profile of paralytic shellfish poisoning toxins in Jinhae bay, Korea. Fish Aquat Sci 16, 137-142.

Mora S, Scott WF, Eric W and Sabine A. 2004. Distribution of heavy metals in marine bivalves, fish and coastal sediments in the gulf and gulf of Oman. Mar Pol Bull 49, 410-424.

Sho YS, Kim JS, Chung SY, Kim MH and Hong MK. 2000. Trace metal contents in fishes and shellfishes and their safety evaluation. J Korean Soc Food Sci Nutr 29, 549-554.

Sivaperumal P, Sankar TV and Viswanathan Nair PG. 2007. Heavy metal concentrations in fish, shellfish and fish products from internal markets of India vis-a-vis international standards. Food Chem 102, 612-620.

Statistics Korea. 2013. Korean statistical information service (KOSIS). Accessed 22 August 2013, http://kosis.kr/index/index.jsp.

Storelli MM. 2008. Potential human health risks from metals ( $\mathrm{Hg}, \mathrm{Cd}$, and $\mathrm{Pb}$ ) and polychlorinated biphenyls (PCBs) via seafood consumption: Estimation of target hazard quotients (THQs) and toxic equivalents (TEQs). Food Chem Toxicol 46, 2782-2788.

U.S. Environmental Protection Agency (EPA). 2013. Human health risk assessment. Accessed 6 August 2013, http://www.epa.gov/reg3hwmd/risk/human/index.htm. 